\title{
Recent Books and Journals Articles in Public Opinion, Survey Methods, Survey Statistics, and Big Data. 2016 Update
}

Mario Callegaro*

Tags: big data, survey statistics, public opinion polling, survey methodlogy, books

\section{Survey Practice}

Vol. 10, Issue 1, 2017

\begin{abstract}
Welcome to the 8 th edition of this column on recent books and journal articles in the field of public opinion, survey methods, survey statistics, and Big Data. This year I officially added Big Data to the title as there is very strong interest on the topic and surveys and Big data are becoming more and more interrelated. This article is an update of the April 2015 article. Like the previous year, the books are organized by topic; this should help the readers to focus on their interests.

It is unlikely to list all new books in the field; I did my best scouting different resources and websites, but I take full responsibility for any omission. The list is also focusing only on books published in English language and available for purchase (as ebook or in print) at the time of this review (August 2016). Books are listed based on the relevance to the topic, and no judgment is made in terms of quality of the content. We let the readers do so.
\end{abstract}

Welcome to the 8th edition of this column on recent books and journal articles in the field of public opinion, survey methods, survey statistics, and Big Data. This year I officially added Big Data to the title as there is very strong interest on the topic and surveys, and Big Data are becoming more and more interrelated.

This article is an update of the April 2015 article. Like the previous year, the books are organized by topic; this should help the readers to focus on their interests.

It is unlikely to list all new books in the field; I did my best scouting different resources and websites, but I take full responsibility for any omission. The list is also focusing only on books published in English language and available for purchase (as ebook or in print) at the time of this review (October 2016). Books are listed based on the relevance to the topic, and no judgment is made in terms of quality of the content. We let the readers do so.

If you want to send information for the next issue, please send it to surveyprac tice.new.books@gmail.com

\section{JOURNALS SPECIAL ISSUES}

Big Data published a special issue on "Visualization in data science". Volume 
4, Issue 2, 2016.

International Journal of Social Research Methodology published a virtual issue on "Visual research methods". 2016.

Journal of Applied Statistics published a special issue on "Statistics in the social sciences”. Volume 43, Issue 13, 2016.

Journal of Official Statistics published a special issue on "Emerging trends and challenges for official statistics”. Volume 31, Issue 2, 2015.

Journal of Official Statistics published a special issue on "Coverage problems in administrative sources”. Volume 31, Issue 3, 2015.

Methods, Data and Analysis (MDA) published a special issue on "The collection of survey data using mixed devices”. Volume 9, Issue 2, 2015.

Political Analysis published a virtual issue on "Recent innovations in text analysis for social science”. 2016.

Psibologija published a special issue on "Survey participation and response". Volume 48, Issue 4, 2015.

Political Analysis published a special issue on "Time series" Volume 24, Issue $1,2016$.

Public Opinion Quarterly published a special issue on "Party polarization" Volume 80, Issue S1.

Public Opinion Quarterly published a virtual issue on "Coloring public opinion". 2016_-_

Social Science Computer Review published a special issue on "Methods for probability-based online and mixed-mode panels”. Volume 34, Issue 1, 2016.

Sociological Methods and Research published a special issue on "Case study research: putting the Quant into the Qual”. Volume 45, Issue 3, 2016.

Statistics in Transition published a special issue on "The measurement of subjective well-being in survey research”. Volume 16, Issue 3, 2015.

Statistical Journal of the IAOS published a special section on "Data fabrication in surveys". Volume 33, Issue 3, 2016.

Survey Practice published a special issue on "Interviewer-respondent interaction”. Volume 9, Issue 2, 2016.

"Annual Reviews critically reviews the most significant primary research literature to guide researchers to the principal contributions of their field [...] Each article is its own search engine, providing a gateway to the essential primary research literature referenced within each topic" (from the Annual 
Reviews website).

Relevant to our topics are three reviews published recently:

Bollen, K.A., P.P. Biemer, A.F. Karr, S. Tueller and M.E. Berzofsky. 2016. Are survey weights needed? A review of diagnostic tests in regression analysis. Annual Review of Statistics and Its Application 3(1): 375-392.

Chandler, J. and D. Shapiro. 2016. Conducting clinical research using crowdsourced convenience samples. Annual Review of Clinical Psychology 12(1): 53-81.

Cuesta, B. de la and K. Imai. 2016. Misunderstandings about the regression discontinuity design in the study of close elections. Annual Review of Political Science19(1): 375-396.

\section{PUBLIC OPINION BOOKS}

Asher, H. 2016. Polling and the public. What every citizen should know (9th ed.). CQ Press, Thousand Oaks, CA.

Bardes, B.A. and R.W. Oldendick. 2016. Public opinion. Measuring the American mind (5th ed.). Rowman \& Littlefield, Lanham, MD.

Clawson, R.A. and Z.M. Oxley. 2016. Public opinion. Democratic ideals, democratic practice (3rd ed. revised). CQ Press, Washington, D.C.

Enns, P.K. 2016. Incarceration nation. How the United States became the most punitive democracy in the world. Cambridge University Press, Cambridge, MA.

Hersh, E.D. 2015. Hacking the electorate. How campaigns perceive voters. Cambridge, New York.

Jungherr, A. 2015. Analyzing political communication with digital trace data: the role of Twitter messages in social science research. Springer, New York.

Stempel, G.H. and T.K. Hargrove. 2015. The 21st-century voter: who votes, how they vote, and why they vote (Vols. 1-2). ABC-CLIO, Santa Barbara, CA.

Wuthnow, R. 2015. Inventing American religion: polls, surveys, and the tenuous quest for a nation's faith. Oxford University Press, Oxford.

\section{SURVEY METHODS BOOKS}

Dabalen, A., Etang, A., Hoogeveen, J., Mushi, E., Schipper, Y. and von Engelhardt, J. 2016. Mobile phone panel surveys in developing countries: $A$ practical guide for microdata collection. World Bank Publications, Washington D.C.

DeVellis, R.F. 2016. Scale development. Theory and applications (5th ed.). Sage, London. 
Engel, U. 2015. Survey measurements: techniques, data quality and sources of error. Campus Verlag, Frankfurt.

Fink, A. 2016. How to conduct surveys. A step-by-step guide (6th ed.). Sage, Los Angeles.

Fox, J.A. 2015. Randomized response and related methods. Surveying sensitive data (2nd ed.). Los Angeles: Sage.

Johnson, R.L. and G.B. Morgan. 2016. Survey scales: a guide to development, analysis, and reporting. Guilford, New York.

Louviere, J.J., T.N. Flynn and A.A.J. Marley. 2015. Best-worst scaling: theory, methods and applications. Cambridge University Press, Cambridge.

Nakray, K., M. Alston and K. Whittenbury. (Eds.). 2016. Social science research etbics for a globalizing world. Interdisciplinary and cross-cultural perspectives. Routledge, New York.

Panel on Addressing Priority Technical Issues for the Next Decade of the American Community Survey, Committee on National Statistics, Division of Behavioral and Social Sciences and Education. 2015. Realizing the potential of the American Community Survey: challenges, tradeoffs, and opportunities. National Academies Press, Washington, D.C.

Ruel, E., W.E.I. Wagner and B.J. Gillespie. 2015. The practice of survey research. Theory and applications. Sage, Los Angeles, CA.

Snee, H., C. Hine, Y. Morey, S. Roberts and H. Watson. (Eds.). 2016. Digital methods for social science. An interdisciplinary guide to research innovation. Palgrave Macmillan, New York.

Toepoel, V. 2016. Doing surveys online. Sage, London.

Williams, C. 2015. Doing international research. Global and local methods. Sage, London.

Wolf, C., D. Joye, T.W. Smith and Y. Fu. (Eds.). 2016. The SAGE bandbook of survey methodology. Sage, London.

\section{SURVEY STATISTICS BOOKS}

Alvarez, R.M. (ed.). 2016. Computational social science. Discovery and prediction. Cambridge University Press, New York.

Bartolucci, F., S. Bacci and M. Gnadi. 2016. Statistical analysis of questionnaires: a unifled approach based on $R$ and Stata. CRC Press, Boca Raton, FL.

Chaudhuri, A., T. C. Christofides and C. R. Rao. (Eds.). 2016. Handbook of statistics 34. Data gathering, analysis and protection of privacy through 
randomized response techniques: qualitative and quantitative. North-Holland, Amsterdam.

Cooper, H. 2016. Research synthesis and meta-analysis. A step-by-step approach (2nd ed.). Sage, Los Angeles.

Dean, A., M. Morris, J. Stufken and D. Bingham. 2015. Handbook of design and analysis of experiments. CRC Press, Boca Raton, FL.

Field, A. 2016. An adventure in statistics. The reality enigma. Sage, London.

Harron, K., H. Goldstein and C. Dibben. (Eds.). 2016. Methodological developments in data linkage. Wiley, Hoboken, NJ.

Kent, R.A. 2016. Analysing quantitative data variable-based and case-based approaches to non-experimental datasets. Sage, London.

Lewis, T.H. 2016. Complex survey data analysis with SAS. CRC Press, Boca Raton, FL.

Mukhopadhyay, P. 2016. Complex surveys. Analysis of categorical data. Springer, Singapore.

Pratesi, M. (Ed.). 2016. Analysis of poverty data by small area estimation. Wiley, Hoboken, NJ.

Quatember, A. 2015. Pseudo-populations. A basic concept in statistical surveys. Springer, Cham.

Raghunathan, T. 2015. Missing data analysis in practice. CRC Press, Boca Raton, FL.

Rao, J.N.K. and I. Molina. 2015. Small area estimation (2nd ed.). Wiley, Hoboken, NJ.

Roy, T.K., R. Acharya and A. Roy. 2016. Statistical survey design and evaluating impact. Cambridge University Press, Delhi.

Stemmler, M., A. von Eye and W. Wiedermann. (Eds.). 2015. Dependent data in social sciences research. Forms, issues, and methods of analysis. Springer, Cham.

Weakliem, D. 2016. Hypothesis testing and model selection in the social sciences. Guilford Press, New York.

Wywial, J.L. 2015. Sampling designs dependent on sample parameters of auxiliary variables. Springer, New York.

\section{BIG DATA, SOCIAL MEDIA, DATA VISUALIZATION, AND OTHER RELEVANT BOOKS}

Berinato, S. 2016. Good charts: The HBR guide to making smarter, more 
persuasive data visualizations. Harvard Business Review Press, Boston, MA.

Bruno, I., F. Jany-Catrice and B. Touchelay. (Eds.). 2016. The social sciences of quantification. From politics of large numbers to target-driven policies. Springer, New York.

Bühlmann, P., P. Drineas, M. Kane and M. van der Laan. (Eds.). 2016. Handbook of Big Data. CRC Press, Boca Raton, FL.

Caffo, B., R.D. Peng and J. Leek. 2016. Executive data science. A guide to training and managing the best data scientists. Leanpub.

Cairo, A. 2016. The truthful art: data, charts, and maps for communication. New Riders, San Francisco.

Evergreen, S.D.H. 2016.) Effective data visualization. The right chart for the right data. Sage, Los Angeles.

Foster, I., R. Ghani, R.S. Jarmin, F. Kreuter \& J. Lane. (Eds.). 2016. Big Data and social science: a practical guide to methods and tools. CRC Press, Boca Raton, FL.

Hai-Jew, S. (Ed.). 2016. Social media data extraction and content analysis. IGI Global, Harrisburg, PA.

Hofmann, M. and A. Chisholm. (Eds.). 2015. Text mining and visualization: case studies using open-source tools. CRC Press, Boca Raton, FL.

Ignatown, G. and R. Mihalcea. 2016. Text mining. A guidebook for the social sciences. Sage, Thousand Oaks, CA.

Kirk, A. 2016. Data visualisation. A bandbook for data driven design. Sage, London.

Knaflic, C.N. 2015. Storytelling with data: A data visualization guide for business professionals. Wiley, Hoboken, NJ.

Liu, B. 2015. Sentiment analysis: mining opinions, sentiments, and emotions. Cambridge University Press, New York.

Peng, R.D. and E. Matsui. 2016. The art of data science. A guide for anyone who works with data. Leanpub.

Vis, F. and M. Thelwall. 2016. Researching social media. Sage, London. 